\title{
Reviews
}

\section{Donald Hawes. Who's Who in Dickens. London and New York: Routledge, 1998,} 278 pp.

Charles Dickens's works are increasingly appealing to scholars, researchers, international conferences and scientific journals. Up till now there has been limited documentation of the innovative aspects of Dickens's prose: idioms, lexical items, special uses of words that he introduced and are in currency today. Among his contributions to the English language, I would like to stress the names of Dickens's own characters since many of these names have become institutions, embodying typical behaviour or typical qualities, and some of them have acquired proverbial status.

Dr. Donald Hawes's Who's Who in Dickens has the value of being a reasonable response to a demand for books guiding readers through Charles Dickens's creation of characters. The predecessors to which it can most directly be compared are John Greaves's 1972 volume, also called Who's Who in Dickens, and Alex Philip and Gadd Lawrence's 1989 edition of The Dickens Dictionary. Dr. Hawes's book covers more of the fiction: the Christmas Stories, tales like "George Silverman's Explanation" and "Hunted Down," the children's stories which include "A Holiday Romance," and "The Mudfog Papers." Who's Who in Dickens gathers together material we would hesitate to classify as fiction, for instance, "The Pantomime of Life" and The Uncommercial Traveller. This guide provides Dickens's plays and collaborative works such as some of the Christmas Stories and $M r$. Nightingale's Diary.

Generally acknowledged as one of the greatest novelists in the English language, Charles Dickens rooted the strength and humour of his fiction in a wide variety of created characters. Who's Who in Dickens is a comprehensive guide to the countless characters in Dickens's fiction. George Newlin, in his Everyone in Dickens (1959), has identified 13,143 characters, but Dr Hawes knows that the inclusion of an exhaustive and definitive list is beyond the scope of his guide aiming to be handy and affordable. Who's Who in Dickens is the result of a mature judgment with the provision of background information about 1,650 characters from the main body of Dickens's work. All the classes of Victorian society are to be found in his fiction: the old aristocracy (Cousin Feenix and Sir Leicester Dedlock), "swells" (Jem Harthouse and Edmund Sparkler), the speculators and the nouveaux riches (the Merdles and the Veneerings), middle-class professional people (Doctor Strong, Allan Woodcourt and the northern ironmaster), lower middle-class shopkeepers and clerks (Mr. Venus and Mr. Guppy), shabby-genteel men (Dick Swiveller), the working class (Mr. Toodle and Mr. Plornish), fortune-hunters and adventures (Montague Tigg and Rigaud), outcasts (Rudge and Martha Endell), and the downtrodden (the Marchioess and Jo).

Who's Who in Dickens reflects one of the richest fields of Dickens as a linguistic innovator since the great Victorian novelist initiates a treatment in the technique of characterising people by naming them. Many of these names have become institutions, reflecting typical behaviour or typical qualities and, above all, the creation of these names 
and characters has enriched the English language. Kelsie Harder has emphasized that Dickens was a master at concocting names with tonal and allegorical qualities and the "inimitable" Victorian could not have been the novelist he was without these names, which contributed so much to his popularity and somehow fixed forever in the English language such names as Gradgrind, Pickwick, Bounderby, Pecksniff, Gamp, Dombey, Micawber, Posnap, Weller. And what is more, these names have been prolific: Pecksniff (in Martin Chuzzlewit) has generated at least the following forms: Pecksniffery, Pecksniffïsm, Peckniffianly, Pecksniffingly; Micawber (in David Copperfield) has also been prolific: Micawberish(ly), Micawberism, Micawberite; Gradgrind (in Hard Times) has produced Gradgrinding, Gradgrindism; Podsnap (in Our Mutual Friend) has three derivations: Podsnappery, Podsnap(p)ian, Podsnapism; Weller (in Pickwick Papers) has produced the term Wellerism and two adjectives: Welleresque and Wellerian.

In Dr. Donald Hawes's Who's Who in Dickens we miss some of the brilliant advances of those researchers who have delved into the fascinating world of the origin and meaning of the Dickensian characters. Among these contributions we should include Kelsie Herder, "Charles Dickens Names His Characters," Names 7 (March 1959): 35-42; Stanley Gerson, "Name-Creation in Dickens," Moderna Sprak 69.4 (1975): 299-315; Stephen R. Rounds, "Naming People: Dickens's Technique in Hard Times," Dickens Studies Newsletter 8.2 (June 1977): 36-40; Knud Sorensen, Charles Dickens: Linguistic Innovator (Arkona: Aarhus Universitet, 1985). Through this help, students and lovers of Dickens's fiction will be in the fortunate position of discovering the calculated and careful process adopted by the novelist in the creation of names as a technique to portray typical behaviour or typical qualities.

Adolfo Luis Soto Vázquez

Charles Dickens. Hard Times. Intr., glossary, and notes by Adolfo Luis Soto Vázquez. La Coruña: Servicio de Publicaciones de la Universidad de La Coruña, 1996.

The University of La Coruna Press has recently released a new edition of Hard Times, one of Dickens's most accomplished works and a sui generis representative of the so-called "Condition of-England novel," which, in Victorian times, portrayed the evils of industrialism, the unfairness of economic laissez-faire, the suffering of the working classes, and, in the particular case of this novel, the inadequacy of an educational system based exclusively on the utilitarian handling of facts. This edition is the more welcome because it does not attempt to compete with other scholarly editions of Dickens's novels; rather, it has been designed as a students' text from the outset and exhibits every feature we have come to associate with books of this kind. First, it should be pointed out that it is not headed by a lengthy and heavy-going introduction. Instead, the reader finds a series of short sections entitled "Hard Times as a Weekly Serial," "Background," "Criticism," "The Naming of Characters," "Lancashire Dialect," "Circus Slang," and "The Education System," all of them, as can be seen, directly relevant to the main stylistic and thematic aspects of Dickens's novel. In "Hard Times as a Weekly Serial," Dr. Soto Vázquez 
examines the process of publication of Hard Times and how its final title came to be chosen among fourteen alternatives; in "Background," there is a selection of letters about Hard Times addressed by Dickens to Victorian intellectuals and men of letters such as John Forster, Mark Lemon, Peter Cunningham, Charles Knight, and Thomas Carlyle; in "Criticism," we find three critical excerpts about this novel by Hippolyte Taine, John Ruskin, and F. R. Leavis; and so forth. The section called "The Education System" is of particular interest because Hard Times notoriously combines a critique of the working conditions in the nineteenth-century industrial city of Preston-under the fictitious name of Coketown-with an indignant satire on the education given to young children in the Gradgrind school following the wake of Jeremy Bentham's utilitarian philosophy.

Apart from these introductory sections, Dr. Soto Vázquez's edition is complemented by a chronology of Charles Dickens's life and publications, a glossary of Lancashire dialectal forms, substandard words and circus slang, a fourteen-page section of explanatory notes to the text of Hard Times, and a substantial bibliography. Fifteen years after the publication of Dr. López Ortega's edition of Hard Times by Alhambra in 1981, this new edition of Dickens's classic novel stands out as a valuable addition to the array of annotated and commented English literary texts now available to Spanish university students.

José Antonio Álvarez Amorós

\section{J. A. Hurtley, B. Hughes, R. M. González Casademont, I. Praga y E. Aliaga. Diccionario cultural e histórico de Irlanda. Barcelona: Ariel, 1996.}

In the introduction to the book the authors refer to the increasing interest in everything related to Ireland and her culture over the last few decades.The film industry, musical groups and leading literary figures have helped to forge a new image of Ireland. Films like The Quiet Man or The Commitments, celtic groups like The Chieftains or Enya, writers like Yeats, Joyce, Beckett, or Seamus Heaney, each from their own viewpoint contributed to expose one side of Ireland, a small but tremendously complex country. They also complain that some quarters in English Studies are reluctant to admit certain Irish writers belong to an Irish literary tradition, with Harold Bloom's The Western Canon as just one significant example. Besides, as far as Spain is concerned, there is an almost complete ignorance of Irish affairs beyond what is highlighted in the media which produces a distorted vision of real Ireland.

The dictionary is precisely aimed at filling that gap. It is really a most interesting and helpful reference book which will be essential for the student, the ordinary reader interested in Ireland, and the scholar alike. Perhaps, one is somewhat surprised at the beginning to find the items in English when the book is in Spanish. The explanation to that is given in the introduction; however, to a certain extent, that involves a fairly high knowledge of English and ordinary readers might be discouraged by this way of presenting the information. The contents provide very important definitions and explanations of Irish cultural and historic events, mainly devoted to the 20th century, although that does not mean that references to the past are ignored. In fact, anyone 
looking for the meaning of immram or rapparee, for instance, will find valuable information, and these are two items selected at random which are very important if we are to understand part of the Irish past. The same could be said of other terms or expressions related to contemporary Ireland found in the dictionary: gallowglass, hooker, sash, ivy, B-specials, England's difficulty, etc. All of them are present in contemporary Irish literature and one wonders about the reader's understanding of the text without a knowledge of their specific implications.

In one way, Diccionario cultural e histórico de Irlanda and Robert Welch's The Oxford Companion to Irish Literature also published in 1996 are complementary. As we can gather from the title their scope is different but $I$ think that the first is more ambitious and valuable for everyone in Spain who is not acquainted with Ireland's rich culture. Apart from providing a great amount of necessary information about historic feats and events, the dictionary also gives detailed references of authors and their output, which makes it very useful. Two little things one would like to add. First, there is no mention of The Freeman's Journal (1763-1923), whereas less important journals are registered, and secondly, there are two items, Molly Bloom and Anna Livia, which stand for the only fictional characters included in the dictionary and one does not exactly know why only these two were selected when there is no mention of any others.

The Diccionario cultural e histórico de Irlanda is a very valuable book which comes to fill a place in Irish studies, and I am sure it will benefit to those interested in Ireland. It is a landmark in Spain for the popularisation of Irish culture and it provides encouragement for those who have already started contributing to a better knowledge of Ireland and her culture in Spain.

Antonio Raúl de Toro Santos

\section{Ronald Carter and John McRae. The Routledge History of Literature in English: Britain and Ireland. Fwd. Malcolm Bradbury. London and New York: Routledge, 1997.}

Histories of literature are necessary. Both students and teachers require them as a guide not only for their courses but also as an indication of the accepted literary cannon and of the critical approach assumed by the academy. The present one is an excellent example of that type of text. It reflects contemporary postmodern views on literary studies including a revision of the cannon that offers, for instance, space for women's voices in all ages, thus acknowledging the importance of literture by women. Together with that the work provides full information about authors, literary movements and the different periods in which they flourished.

It is a book written for a wide audience, probably a global one, as it covers the needs and interests of both native and non-native readership in that cultural, historic and linguistic aspects are analysed in a manner useful for any literature student. One may imagine how difficult it is nowadays to give a title to a work such as the present one, so that it looks like the standard work (the one and only book to be chosen by the market) and, at the same time, it has a mark of distinction that makes it unique. In this case the 
very title shows how "History of English literature" is a phrase that has to be somewhat modified to isolate the literary product offered. This is achieved by means of the publishers' trademark that acts as a guarantee. Moreover, the title is qualified to avoid colonial or anglocentric connotations and the full message of both title and subtitle is that of a reliable, up-to-date, prejudices-free, literary history. The content of this carefully designed book fully strengthens the message included in its emblematic title and matches the prestige of the publisher, as it offers value for money.

Another outstanding feature of this volume is that it is a history of literature in which not only history but also literature is present. This is achieved by means of abundant quotations throughout the text and placed even as well-selected paragraph titles which give the text a literary flavour absent in many other literary histories. The work has a special emphasis on modern and contemporary literature since these are the most widely studied periods of English literature. As it may be seen from the mere space given to the different periods, the twentieth century requires approximately two hundred pages whereas old, middle, and renaissance literature cover little more than a hundred. Obviously, this is due to the quantity of texts preserved from ancient periods, to the importance of the printing press, and to the increase of the reading public that built a whole literary industry in the present century. However, although this is not not necessarily criticizable, one cannot avoid the feeling that the authors have a special interest for modern literature to the detriment of other periods. This may be due to the lack of perspective that we all have about the literary products of our age as they have not yet been filtered through time.

As a whole we can say that we have before us a carefully written work that has all the essential features (including index, Timelines by Jeremy Hunter, and Nobel Prize Winners list) to become a widely considered reference and text book in both schools and universities, useful for students and scholars of English literature throughout the world. It is crystal clear, easy to read and, at the same time, scholarly and accurate in that it faithfully represents the panorama of the literary production of a linguistic community throughout the centuries.

María Jesús Lorenzo Modia

\section{Margaret Atwood. Strange Things: The Malevolent North in Canadian Literature. Oxford: Clarendon, 1995, $126 \mathrm{pp}$.}

This book consists of four lectures delivered by Margaret Atwood at Oxford University in the spring of 1991. In the Introduction Atwood makes it clear that she focuses on the mystique of the Canadian North and its influence on Canadian Literature as a whole, and that she speaks from her position as a non-scholar. To illustrate this, Atwood points out how she tried to match her earrings to the subject matter of each of her lectures; something, she claims, that a respectable academic would not have done.

The first lecture opens up with the problems involved in the definition of the Canadian identity. Atwood states that "the search for the fabled Canadian identity is like a dog chasing its own tail" (8) and this statement shows how the situation has changed since she published Survival in 1972. In the seventies Atwood wrote a book to put Canada in the 
literary world map, but now this is unnecessary because "there is the tail, as firmly attached to the dog as ever" (8). In Strange Things Atwood brings to light a collection of hackneyed images and stories, usually associated with the Canadian North, which exert a powerful fascination on Canadian writers so as to rework these motifs in their poems and novels, all of them written in English. Her first lecture thus focuses on one particular recurring motif: the failure of the Franklin expedition when they tried to discover the North-west Passage. As Franklin was never found, according to Atwood "he continues to live on as a haunting presence; certainly in Canadian literature" (16). Indeed, the author gives examples of literary works where the Franklin expedition is somehow present, but underpinning all those works is the concept of the North as an uncanny, hostile although alluring, environment. For example, E. J. Pratt felt so attracted to the Franklin story that he attempted to write it more than once, but he eventually wrote an epic on the sinking of the Titanic, another maritime disaster. Atwood's contention is that Pratt introduces some of the Franklin expedition story's elements as well as her own conception of the North as a powerful influence into his Titanic poem. Therefore, the first literary treatment that Atwood finds of this topic is Gwendoline MacEwen's verse drama Terror and Erebus (1963). After a period in which the Franklin story's mythic quality is undermined by several literary works, Graeme Gibson's 1982 novel Perpetual Motion takes up the serious quality of the motif again. In order to finish her first lecture, Atwood mentions other writers who have dealt with Franklin and his expedition, namely Mordecai Richler, and Rudy Wiebe. The song "The Northwest Passage" (1981), written by the Canadian singer Stan Rogers, also makes specific reference to northern explorators, including Franklin.

The second chapter is titled "The Grey Owl Syndrome" after the Englishman who in the nineteenth century emigrated to Canada, lived with the Indians, and once adopted by them, became a well-known writer and lecturer. "The Grey Owl Syndrome" refers to a good many non-Natives who want to turn themselves into Natives, and who see the wilderness as having enhancing power and renewing life. Two nineteenth-century writers were precursors of Grey Owl: John Richardson, who wrote Wacousta in 1832, and Ernest Thompson Seton. Thompson Seton's life and work provided the idea that one had to live like the Indians in the wilderness to survive the advancing decadence of white civilization. His 1912 Book of Woodcraft encapsulated the most positive values and attitudes towards the Indians ever seen. Here Atwood concentrates on Seton's long-lasting influence as well as on the way he developed a Woodcraft Indian Movement along democratic lines to be later "stolen from him by Baden-Powell and converted into the Boy-Scouts" (46). But it is Grey Owl who continues living in the literary pieces of some writers, and among them is Robert Kroetsch's 1973 novel Gone Indian. Atwood finally recognizes that the wish to go Indian is quite embedded in the Canadian culture, something she congratulates on, since in her opinion white society should learn from the Native attitude towards nature to stop environmental damages.

The third chapter deals with the myth of the dreaded snow monster, the multi-faceted Wendigo, an incarnation of going crazy in the North, and with the ways in which this myth has become a motif in Canadian literature. Atwood gives a rather useful introduction to this myth to an English audience, probably not acquainted with the Wendigo stories and tales. It is interesting to note the differences Atwood establishes between the Wendigo, 
confined to the eastern woodlands, and other man-eaters. When the Wendigo is mentioned by non-Natives in short and lyric poems, it stands for an object of meditation-humans themselves are potential monsters. But in longer pieces of literature Wendigoes tend to play the same role as ghosts in the ghost story or Gothic tale. In this sense, Atwood distinguishes three different ways of presenting the monster in relation to human characters: in the first kind of story, Wendigoes can be considered spirits of places. In the second kind, the creature is somewhat connected with the human character so that if that character gets eaten, it will be his/her fault i.e. William Henry Drummond's narrative poem "The Windigo" (1901). The third type of story has to do with the concept of being driven mad in Canadian North, which also receives the name of "getting bushed" or "cabin fever". In this specific case the supernatural creature represents a split-off element of the protagonist's psyche, developing a life of its own; here the concepts of getting "bushed" and "going Wendigo" overlap as in Wayland Drew's complex 1973 novel The Wabeno Feast.

The title of the fourth lecture is "Linoleum Caves", a quotation from Alice Munro's Lives of Girls and Women (1971). What strikes Atwood here is the combination of domesticity and wilderness, which leads her to bring the topic of the lecture in: the connections between the Canadian North and women as either authors or fictional characters. Despite the undoubtable presence of Canadian women writers, Atwood points out that there are neither myths concerning women and exploration nor many stories about women who wanted to become Indians like Grey Owl. However, some women have incorporated Indian motifs to their own works, namely, Susan Musgrave and Sheila Watson. The nearest thing to Grey Owl is E. Pauline Johnson, who succeeded as a performance artist and a poet in the last decades of the nineteenth-century. As there were some women who ended up in the woods, Atwood tries to establish a distinction between what she calls "the first wave", women of the nineteenth century who went to the woods because circumstances led them there, and "the second wave", those women of the twentieth century who following these first women write about them. In this sense, Anna Jameson and the sisters Susanna Moodie and Catharine Parr Traill offer three different viewpoints of the relation between women and the wilderness. The sisters' visions of a settler's life differ considerably, so whereas Traill's book is a practical book designed for prospective settlers, Moodie's Roughing It In the Bush is a warning to immigrants, emphasizing hardship and danger. Then, around the middle of the twentieth century, Canadian female protagonists start going off into the woods to be by themselves i.e. Maggie Vardoe in Ethel Wilson's 1954 novel Swamp Angel. More important, Marian Engel takes her heroine beyond humanity and close to Nature in her 1976 novel Bear, where she actually falls in love with a bear. The protagonist's quest to an island in Northern Ontario ends up when she finds in that creature the source for her spiritual renewal, achieving, in Atwood's words, "an authentic, strong self" (109). Margaret Atwood herself wrote her own woman-in-the-woods-novel back in 1972, Surfacing; insofar as both novels are female psychic quests, I think that at this point some commentary on her novel in relation to Engel's Bear could have brought some light to the subject. Regarding the Wendigo legend, Atwood finds the first female incarnation of this myth in Ann Tracy's 1990 novel Winter Hunger. 
Margaret Atwood finally links her own work to some of the imagery and Native lore she has been discussing, which gives a sort of circular structure to the book. What one misses here perhaps is a much more detailed analysis of her own writing, inextricably linked to the imagery of the Canadian North, a Canadian North which could cease to exist because of pollution and environmental carnage. She thus finishes her fourth lecture, and this book, by drawing the listener's, and the reader's, attention to environmental problems in Canada. Strange Things offers a fascinating portrait of the Canadian North, and an insight into the Canadian literary imagination. Both informative and exciting, it provides a very illuminating understanding of the mysterious North and of its lore, which has always allured poets and novelists alike. Atwood's Strange Things constitutes then a useful book to those who want to focus on the relationship between the Canadian North and story-telling, as well as a valuable piece of literature in itself.

Rosario Arias

Charles Bernheimer (ed.), Comparative Literature in the Age of Multiculturalism, Baltimore \& Londres, The John Hopkins University Press ("Parallax; Re-visions of Culture and Society"), 1995, 207 pp.

The volume that we are commenting is composed of three parts. If we do not take into account Bernheimer's preliminary chapter on "The Anxieties of Comparison", the first part gathers "Three Reports to the American Comparative Literature Association", elaborated by the commissions that presided professors Harry Levin in 1965, Thomas Greene in 1975 and Charles Bernheimer in 1993. These are the successive reports that have oriented their guidelines in the exercise of the comparative literature as an accademic discipline in American Universities. In the second part come together "Three Responses to the Bernheimer Report at the Modern Language Association Convention, 1993". The book is completed with a section of "Position Papers", in which appear thirteen articles prepared after the debate provoked by the Bernheimer Report, in 1993.

The paper entitled "Comparative Literature at the Turn of the Century" is the central one in this volume, for it contains many recommendations to renove the comparative research and to shape the new universitary Programs of Comparative Literature at Graduate and Undergraduate levels. Berheimer's Report, trying to sum up hte mos relevant contents of 1965 and 1975 previous Reports, draws a living picture of the major vicissitudes and mutations that comparative studies have experienced in the last thirty years. The editor of those Reports pointed out the growth of the discipline after World War II, based in the adoption of broader perspectives, but after all, it "did not often reach beyond Europe's high-cultural lineage going back to the civilizations of classical antiquity" (p. 40). That situation lead "to reinforce an identification of nation-states as imagined communities with national languages as their natural bases" (p. 40). In spite of warning about the dangers that threatened the comparativism of those days, inspired by traditional and immobilized conceptions, Levin and Green complained against the attempts of mining "the very basis of comparative literature's elite image" (p.40) of those who, by reasons of comfort, adopted translations instead of commenting the texts in their 
original languages. They also manifested some reserve towards multidisciplinarity, as it showed an inherent impunity in the diversification of approaches, and towards literary theory, that was in fashion during the seventies.

The authors of the 1993 Report figth for a radical redefinition of goals and methods, since, as they admit, "the dangers confronting the discipline thus constructed [in the traditional eurocentric way] have only intensified in the seventeen years since the publication of the Green report, to the point that, in the opinion of this commitee, the construction no longer corresponds to the practices that currently define the field" (p. 41).

In the nineties those practices have got in tune with the multicultural trends which have pervaded the speech of Humanities. In this case, the new bias intended for the subject is dangerously adjacent to the so-called "Cultural Studies", a field that has arisen many intellectual ravings. As it is already known, the criticism addressed to mulculturalism - and it should be remembered that the attacks have been formulated not only from retrograde ideological fields- maintains that it breathes the wish that all cultures be treated on equal terms, in an attempt, more o less unconfessed, of destruction and refill of imposed cultural prestiges -if we echo well known arguments- arrogantly enough through the political action of the western colonizer powers and because of the patriarcal preponderancies that should be eliminated now, given the failure of previous efforts, more conciliatory and moderate, to put them a stop. To tell the truth, Bernheimer's Report sanctions a given situation, that is sumed up in the following terms: "The space of comparison today involves comparisons between artistic productions usually studied by different disciplines; between various cultural constructions of those disciplines; between Western cultural traditions, both high and popular, and those of non-Western cultures; between the pre- and postcontact cultural productions of colonized peoples; between gender constructions defined as straight and those defined as gay; between racial and ethnic modes of signifying; between hermeneutic articulations of meaning and materialist analysis of its modes of production and circulation; and much more" (p. 42). This directly flows into one of the most controversial thesis of the Report - severely criticized by Rifaterre in the same volume, in one of the commentaries to the 1993 guidelines-: " These ways of contextualizing literature in the expanded fields of discourse, culture, ideology, race, and gender are so different from the old models of literary study according to authors, nations, periods, and genres that the term "literature" may no longer adequately describe our subject of study" (p. 42). Nevertheless, to that is added the reserve that "our recommendation to broaden the field of inquiry [...] does not mean that comparative study should abandon the close analysis of rhetorical, prosodic, and other formal features but textually precise readings shooooould take account as well of the ideological, cultural, and institutional contexts in which their meanings are produced" (p. 43). With regard to language knowledge, it is recommended to the students of the speciality "to broaden their linguistic horizons to encompass at least one non-European language" (p. 43), though "the old hostilities toward translation should be mitigated" (p. 44), since firstly "translation can well be seen as a paradigm for larger problems of understanding and interpretation across different discursive traditions" (p. 44) y also because "it may be better, for instance, to reach a work in translation, even if you don't have acess to the original language, than to 
neglect marginal voices because of their mediated transmission" (p. 44). The canon's formation and reshaping is to be, of course, another

central issue of the new comparativism: "comparative literature courses should teach not just "great books" but also how a book comes to be designated as "great" in a particular culture, that is, what interests have been and are invested in maintaining this label" (p. 46). Summing up the authors' goals, it is affirmed: "Our report puts forward some guiding ideas about the way curricula can be structured in order to expand students' perspectives and stimulate them to think in culturally pluralistic terms" (p. 47).

As we have already said, the volume includes three answers to the 1993 Report. Dissenting in many points is Michel Rifaterre's essay, "On the Complementarity of Comparative Literature and Cultural Studies". More consently are those of Anthony Appiah ("Geist Stories") and Mary Louise Pratt ("Comparative Literature and Global Citizenship"). The authors of the papers that complete the work are researches of american universities: Ed Ahearn and Arnold Weinstein ("The Function of Criticism at the Present Time: The Promise of Comparative Literature"), Emily Apter ("Comparative Exile: Competing Margins in the History of Comparative", Peter Brooks ("Must We Apologize?"), Rey Chow ("In the Name of Comparative Literature"), Jonathan Culler ("Comparative Literature, at Last!"), David Damrosch ("Literary Study in an Elliptical Age"), Elisabeth Fox-Genovese ("Between Elitism and Popularism: Whither Comparative Literature?"), Roland Greene ("Their Generation"), Margaret R. Higonnet ("Comparative Literature on the Feminist Edge"), Françoise Lionnet ("Spaces of Comparison"), Marjorie Perloff ("'Literature' in the Expanded Field"), Mary Russo ("Telling Tales out of School: Comparative Literature and Disciplinary Recession"), Tobin Siebers ("Sincerely Yours").

Santiago Navarro Pastor - Heinrich Heine-Universität Düsseldorf

\section{Esther Morillas y Juan Pablo Arias, eds. El papel del traductor. Salamanca: Ediciones Colegio de España, Biblioteca de Traducción, 1997, 509 pp.}

It is no exaggeration to say that translation has become one of the foundations on which our modern life is built. Indeed, the importance of translation is now more and more widely acknowledged. This is certainly the case in the academic domain, since, for the last two decades, experts in the field have been wholeheartedly proclaiming the autonomy of Translation Studies as an independent discipline. But even the layman will concede that, in the era of supranational political decision-making, cross-border regulation, thriving international trade and global cyberculture, one cannot do without translation.

However, this widespread belief contrasts with the paradoxical underestimation of the translator's status and responsibilities. In the social arena, the translator's task receives low regard, probably due to the general unawareness of the specific skills and the high degree of specialization required. As for theory, many questions concerning how the personal stance of the translator influences the final product still remain unanswered. From a historical point of view, the importance of translators in the shaping of particular cultures 
needs to be assessed. It is no coincidence that all these aspects are dealt with in El papel del traductor, edited by Esther Morillas and Juan Pablo Arias.

As its title partly suggests, this collection of papers provides a thorough and critical examination of the translator's role in the light of the increasing need for competent professionals, as the recent founding of faculties specialized in translation training in Spain clearly illustrates. Beyond these evident expectations, however, the book comes to valuable and innovative conclusions, derived from both the academic research on diverse current trends of Translation Studies and the experience of practising translators.

To help the reader, the essays are arranged thematically around four main areas. The first section offers a theoretical approach to the implications of rescuing the translator from invisibility and neutrality - thus becoming an ideologically marked intermediary, a gendered subject, a hermeneutical exegete, a vehicle of progress, etc. In this sense, translators, editors and critics are also provided with a new (ethical) framework where this shift in perception is taken into account. The second section is devoted to the history of translation. Five papers trace the work of particular translators, the constraints imposed upon them at specific points in time and the reception of certain authors and genres through translation. The third section is concerned with describing and assessing concrete translations of texts ranging from the classics to current film versions, from literary and religious masterpieces to legal and journalistic writings. Finally, the translators themselves have the floor. This first-hand information drawn from their experience in a wide variety of specific fields (TV versions, film adaptations of literary works, literary translation of novels and plays, translation as hybridisation) gives empirical evidence of the new situation facing translators, inasmuch as they take on the more prominent and visible role vindicated in this monograph.

We cannot overemphasize the quality and usefulness of El papel del traductor. The brief account of the book provided above speaks for itself. Naturally, it must be acknowledged that, given the professional prestige of the contributors -in most cases attached to the research group of the University of Málaga-, the result could not have been otherwise. Nevertheless, let us take this opportunity to insist on two of the main assets of this book.

First of all, the successful conjunction of theory and practice and the comprehensive nature of the work make it useful and of interest for professionals from various backgrounds. Not only will potential translators be provided with the basic guidelines for responding to the demands of their profession and weighing up the complex implications of their decisions. Teachers of translation will also be reminded of the enormous responsibility involved in the training of cultural mediators as well as persuaded that their approach to translation will have political and ideological repercussions. In addition, practising translators will be able to contrast their views with those of other colleagues and to retrieve the theoretical tenets of their work. Furthermore, the diverse fields tackled (law, dubbing, literature, TV versions) may reveal to them new professional prospects. On the other hand, other professionals might discover how the work of conscious, proficient, competent translators matching the profile outlined in this book may be extremely helpful for their business. For the purpose of El papel del traductor is also - and mainly- to bring to light a neglected, often unknown and unnoticed professional. 
Secondly, the progressive attitude adopted by the contributors paves the way for further study and fosters critical debate in the domain of Translation Studies. In this sense, this book illustrates the increasing interest and concern that this discipline arouses in our country. What is more, the fact that the series in which it has been published is entirely devoted to translation is highly significant. Certainly, publishing houses such as Cátedra have long been making key reference works available to the Spanish-speaking public. Nevertheless, the initiative taken by the University of Castilla-La Mancha in their collection Escuela de Traductores de Toledo and Ediciones Colegio de España in their Biblioteca de Traducción, both exclusively related to translation, shows a specific and praiseworthy commitment to the subject. In this respect, the fairness of the venture is backed by the fact that international publishers such as Multilingual Matters, John Benjamins, Rodopi and Routledge are now succeding in their corresponding series on Translation Studies.

In the case of Biblioteca de Traducción, the contribution to the flourishing of Translation Studies in Spain is twofold. As stated in the General Editors' Preface, the series aims firstly to make the most representative foreign classics on translation available to the Spanish public. This was the goal of the 1997 Spanish version of André Lefevere's Translation, Rewriting and the Manipulation of Literary Fame. Moreover, Biblioteca de Traducción endeavours to divulge the most outstanding output of domestic research. $E l$ papel del traductor thus inaugurates this second orientation and unquestionably sets a standard of excellence which is to be maintained. In any event, the next two titles of the series will surely live up to expectations. Suffice it to say that Mary Snell-Hornby's Translation Studies. An integrated approach is to follow the path opened by André Lefevere. With regard to national projects, in Traducción y cultura: de la ideología al texto, Ovidi Carbonell will develop some of the ideas already outlined in his collaboration to the book here reviewed. No doubt, to offer the degree of brilliance and meticulousness he and the remaining twenty-nine contributors achieve in El papel del traductor.

M. Rosario Martín Ruano

Brian Hollingworth. Maria Edgeworth's Irish Writing. Language, History, Politics. New York and London: Macmillan, 1997.

200 years ago, the French invasion of Ireland in aide of the United Irishmen uprising against colonial rule came to a tragic end in Ballinamuck, north of county Longford, a few miles from Edgeworthtown, where Maria Edgeworth lived and wrote. She has achieved a modest reputation as a pioneer of the regional novel, and her name is generally mentioned as a forerunner of Walter Scott and a possible influence in Turguenev.

Brian Hollingworth, recently retired as Head of English at Derby University, has undertaken a survey of the reasons and influences that motivated a gentlewoman to try a new active approach to fiction in an Irish backwater, and how and why the vernacular came to be used in narrative. Castle Rackrent has attained a canonical niche as a 'minor classic', enshrining the term to describe abusive colonial practices. Edgeworth wrote from personal experience, as she belonged to an Anglo-Irish family, and her writings have not 
escaped political criticism after her death. Rediscovered in recent years by Gender Studies, particularly in the wake of Gubar and Kowalesci-Wallace studies, her oeuvre has been re-evaluated and more of her novels have been reprinted. The present study focuses on works of fiction and non-fiction where the use of Hiberno-English is foregrounded. The titles surveyed belong to the period of joint authorship with her father Richard Edgeworth, and the author bravely approaches a controversial issue through extended citations of unpublished or little known correspondance. His analysis is the outcome of several years of dedicated research and an exhaustive study of sources; he has had access to original correspondence in the National Library of Ireland, to unpublished letters and documents, unpublished private work and contemporary reviews.

Striving for a non-partisan stance, Hollingworth has concentrated on a detailed description of the introduction of Irish background and themes in the books published in the period spanning from the ' 98 Rising up to the first years after the Act of Union. He has selected fiction and non-fiction titles: Practical Education (1798), Castle Rackrent (1800), Essay on the Irish Bulls (1802), Ennui (1809), The Absentee (1812) and Ormond (1817). Any intention to evaluate Edgeworth's ranking as a novelist is disclaimed in the Introduction. He has focused instead on her received reputation as founder of the regional novel, particularly her commitment to Ireland and the pioneering approach to the vernacular. First a brief reference is made to the socio-political context in which Maria Edgeworth developed her writing, the troubled times surrounding the United Irishmen rising in ' 98 and the arrival of forces sent by Revolutionary France in their aide. Hopes of independance or autonomy inspired by the American Rebellion, nurtured by nationalists and by enlightened members of the Ascendancy were crushed by the Act of Union and its aftermath, Edgeworth died in the first Famine years. The various influences that came to play to inspire such an unusual interest in language are presented in Part I. First, Edgeworth has explored Edgeworth's cultural roots in the Enlightenment; The Edgeworths family used to move in cultured circles, they were widely read and familiar with French and English philosophers of the Eighteenth Century. Maria had an unconventional upbringing and a room of her own; friends and family encouraged her writing career. Unlike some of her contemporaries, she belonged to a highly literate family, where it was usual for drafts to be circulated, corrected, reviewed, before a final version was completed, as witness her copious correspondance.

The linguistic theories of Condillac and Monboddo, as well as Locke's empirical approach, were to have a decisive influence in her father and her; they encouraged a new interest in the role of language, and its possible links with the development of reasoning. Hence the importance accorded to the acquisition of good reading habits in childhood, developed in Practical Education. The connection between language and reason is the guiding line in her didactic writings. Hollingworth does not take sides in the controversy surrounding the shared authorship, yet he acknowledges the findings of feminist scholarship, subtly enhancing Maria's role. In particular, he analyses the positive effect derived from Richard Lovel's interest in science, engineering and means of communication. The second main influence was connected with the Lunar Society, a distinguished scientific and industrialist circle in the last part of the Eighteenth Century formed by such leading figures as Wedgwood, Darwin and Watt, of which Richard 
Edgeworth was a founding member. Based in the provinces, centered in the Midlands, independent of metropolitan Establishment circles, it was directly linked to the early industrial revolution. Maria shared their values and their interests. Hence her attention to the details of local language and her habit of social observation, plus a conscious choice of life in the provinces, a commitment to practical reform and improvement of land practices. Such a background made for an unusual non-partisan view of religion, and an idealist belief in the social benefits of progress. The realities of Anglo-Irish life notwithstanding, all the books selected for the present study reflect a conscious desire to improve relations between English and Irish people. Central to a better understanding of Ireland was an understanding of Hiberno-English, not just as a quaint way of talking but as a real and worthwhile way of expression. In the didactic writings, the Edgeworths are very close to a scientific approach to language analysis. Inherent in such undertaking was a sensitivity to changing social conditions characteristic of the Lunar Society. Hollingworth underlines the ambiguities and contradictions in Edgeworth's approach to language resulting from philosophical and Lunar Society influence. Edgeworth's beliefs and attitudes are best portrayed in An Essay on Irish Bulls, written in the same period as Castle Rackrent, although it appeared in 1802. It is also a surprising project, for the times. The political intent is openly declared: to effect a change of attitude in the metropolis vis-à-vis the natives, to prove that the Irish were not inferior despite their quaint way of speaking, to illustrate the blunders or 'bulls' as a different way of speaking. The list of bulls and accompaning stories are thoroughly surveyed. Reference is made to Butler's theory suggesting the Essay be considered as the 'theoretical commentary' to the use of language in Castle Rackrent.

Part II: 'The Irish Tales' is an exhaustive analysis of how the vernacular language, examples, code and register, is central to each book. Taking Young's Tour in Ireland as principal meta-text, Hollingworth argues for a less literal reading of Castle Rackrent, considering 'the glaring choice of Rackrent for the name of the castle' (81) title, implying torture. He argues the importance of content and publication date, explaining the relevance of rushing the publication to forestall the Act of Union, '... when Ireland loses her identity'. He deconstructs the seemingly innocent text, analyses the naive narrator's voice and presents evidence to underline the author's ambiguity about Anglo-Irish relations. The role of preface, glossary and notes, unusual components of published fiction, is examined, reaching the conclusion that it serves to legitimate the vernacular voice in the following ways. First, creating the character of Thady Quirk: an ambivalent figure susceptible of several readings. A superficial copy of Langan, the innocent rural simpleton, a transparent narrator transparent allowing the reader to see through, an Uncle Tom character even, in Harden's opinion. Or a conniving, sly, 'Irish' peasant, revealing a hidden agenda of native irish recovery of their land by any means, as Newcomer feels. Hollingworth also brings up Dunne's contrasting postcolonial argument. Second, inventing Thady and using him as narrator allows a fresh voice, Maria Edgeworth is not constrained by the 'drawing-room' view of the world which Austen defenders are at such pains to justify. Mention is made of discreet reminiscences of Gothic novels. Hollingworth looks closely into the 'vernacular' used in the narrative, highlighting the use of dialectal vocabulary, pronunciation and idiom, as well as the inconsistencies of register and code, 
to conclude that the intention was more to give an 'Irish' flavour than to portray local speech faithfully. Chapter 6, 'Let Us Dare to be Ourselves: A Reading of Ennui', reveals some Gothic features in a story set up in a near romantic celtic setting. Edgeworth's elusive irony however is interwoven in the text, with touches reminiscent of Northanger Abbey. A historical subtext in the plot recalls the tragic events of ' 98 , echoed in the hero's contradictory and inadequate reactions when the rebellion breaks, and he is faced with the ensuing confusion in the land. Woven into the story are direct references to United Irishmen and Defenders, introducing the question of the legitimacy of Anglo-Irish rule within a legal framework at odds with instances of Irish quasifeudal loyalty. The vernacular is subtly granted status: the mother tongue is equated with Hiberno-English, the tongue of the old nurse. Edgeworth is shown to be divided between her drive to use the vernacular and the need to use conventional rhetoric. Hollingworth points out in this section how the emphasis shifts from the representation of a quaint vernacular to the recognition of its qualities of openness and generosity, allied to a subtle accent on the lively wit and sense of humour. Chapter 7 presents 'The Voice Of Truth: A Reading of The Absentee.' Hiberno-English appears again as an important factor in The Absentee, where code switching proves an unsurmountable obstacle for the Anglo-Irish, ironically portrayed as unable to pass for bona fide English, and ridiculed. In McCormack's view (Introduction to 1988 edition), the story deals with the social consequences of the Act of Union, hence the title. In particular, concern about the state of Ireland and the unease about the widening gulf between religious confessions. The conscious option in favour of Ireland is reflected by 'open and hermetic references.... an emblem of a desired but elusive integration' (155). Chapter 8, 'King Or No King: A Reading of Ormond' was the last of the Irish set. Published in 1817, shortly before Richard Lovel's death, marks the end of the Edgeworths collaboration and reflects the despair of both Edgeworths about the 'condition of Ireland'. Earlier hopes of moderate reform had proved unrealistic, the end of the Napoleonic wars and the polarization of political postures after a Union had not improved local conditions, while the Anglo-Irish establishment had lost political initiative. Walter Scott had published Waverley, where he acknowledged Maria Edgeworth's influence. Hollingworth suggested the romantic Bildungsroman was susceptible of an alternative political reading. The text offers a polyphonic blend of vernacular and standard English well in advance of the times. Hollingworth endorses McCormack's term 'vectoric approach' to depict the style full of allusions to Irish culture and history, suggesting tolerance and a growing recognition of a Celtic tradition and the claims of the landless natives. The author examines echoes of Shakespeare's Henry IV Part 1 as well as Troilus and Cressida, as well as discreet reminiscences of Gothic novels. In conclusion, Maria Edgeworth's Irish Writing is a valuable apportation to an understanding of origin of the regional novel, and the evolution of narrative options. Given the dearth of Edgeworth studies, the present up to date bibliography is a particularly welcome guide for further research. Although the book concentrates on the Irish Tales, reference is made to other contemporary Edgeworth's writings, so a complete perpective of her impressive writing activity is offered. Abundant instances of Maria's relation with her father are a useful basis for a reappraisal of the complex problem of shared authorship. He has shown the contradictions and inconsistencies in Richard Edgeworth personna, and his influence on 
his daughter, with ample reference to their conflicting attitudes and their ambiguity in their allegiances. Hollingworth has shed light into some issues, and has indirectly laid the ground for a literary evaluation of the author. Castle Rackrent is presented as part of a large endeavour. The sources and factors that combined to originate the innovating interest for the vernacular language had not been the object of scholarly attention before, and recognition of Hiberno-English is a surprising first in the light of contemporary literary values.

The unprecedented use of the vernacular, to sum up, is restricted by Edgeworth's adherence to Eighteenth Century theories of language. Throughout the book, Hollingworth traces the far reaching influence of the Enlightment on Maria Edgeworth's make up, while he also makes a forceful case for her attachment to Ireland as the driving force of her career. Perhaps one wished he had dwelt deeper in the linguistic issues: English as colonial language, possible transfers from the Gaelic. Assuming English was spoken in Ireland obscures the fact that different meanings may be attached to a single word. Edgeworth was one of the first in her presentation of 'vernacular' and in her avowed intention to bridge the misunderstandings caused by speakers of the two versions. Remarkably non-partisan, Hollingworth's argument supports the view that her attitude reveals deep ambivalence, exploring with profuse detail the ambivalence ensued from the untenable no-woman's land where her upbringing, education, sympathies and intentions had placed Maria Edgeworth.

Pilar Campos Pardillos

Exemplaria. Revista Internacional de Literatura Comparada. Universidad de Huelva, Vol. 1, Año 1997.

The publication in Spain, or merely in Spanish, of a journal monograph dedicated to Comparative Literature has to be welcome. It is true that over the last few years we have witnessed the presentation in our country of several journals with a more or less theoretical and comparatist inclination. Such is the case of Tropelias and, especially, Teoria/Critica, although none of them is devoted completely to comparative literature. The former is rather in the tradition of the miscellany, whereas the latter-always in monograph form-pays more attention to the great epistemological questions and to the theoretical thinking of our age. And we must not disregard the existence, for over twenty years now, of 1616, the journal of the Spanish Association of General and Comparative Literature. In any case, we must admit the absence in our language of a solid tradition of scientific-academic publications focused on comparative studies, whatever its disciplinary horizon. We do have neither a long-standing publication such as the Parisian Revue de Littérature Comparée, the Hungarian Helicon and Neohelicon, or the American Comparative Literature, nor any recent but already established one, such as the Yearbook of Comparative and General Literature.

Exemplaria is edited by Professors Antonio Ramírez de Vergés and Miguel A. Márquez, both of the University of Huelva, and its Managing Editor is Pablo Zambrano. It is an academic journal which, as its editors declare in the first issue, "publishes articles and notes on literary traditions, sources, influences, subjects, motives and themes; history 
of the literary genres; relationships among authors; all of it within the context of Western literature. Only occasionally, so long as the contribution is especially relevant, do we publish essays on literary periods, international relationships and literary theory". This declaration, scarcely comparatist and definitely unpretentious, may sound too restrictive; but the authors do not intend to cover an extensive field of comparatism and theory, as is the case of the aforementioned Yearbook.

Exemplaria contains three sections: articles, notes and reviews. The first section of the first issue includes ten articles. The first one, Pierre Bruynel, is a reflection on the concepts of theme and myth as exemplified by the figure of the labyrinth. This first issue also collects essays by Francisco Abad (on comparative studies in Menéndez Pidal's school), Vicente Cristóbal (on Anaxarete from Ovid to Jorge Guillén), Susana Gil Albarellos (on the Renaissance debates about chivalry), Antonio Garnica (on the Spanish anticlerical novel), Eloisa Nos Aldás (on Hugh MacDiarmid and Emily Dickinson), Luis Gómez Canseco (on mythical and archetypal structures in Sánchez Mazas' novels), Carmen Pérez Romero and Lourdes Nuevo (on the functions of the proper name in the shaping of character), Luisa María Gutiérrez Hermosa (on the theory of the Golden Age novella), and José Enríque Martínez Fernández (on literary influence and textual marks).

As to the "Notes" section, this first issue of Exemplaria contains contributions by Miguel A. Márquez (on variations of the carpe diem topic in Propertius), Montserrat Martínez Vázquez (on a sonnet by Philip Sidney), Zenón Luis Martínez (on Roman caritas in King Lear), and Pablo Zambrano (on John Donne and Ovid's Amori). The rest is complete with excellent reviews of such recent books as D. Blow's Mirabile Dictu: Representations of the Marvelous in Medieval and Renaissance Epic (Ann Arbor, 1996), G. A. Kennedy's A New History of Classical Rhetoric (Princeton, 1994), J. Álvarez Barrientos and J. Checa Beltrán's El siglo que llaman ilustrado (Madrid, 1996), M. Alloin-Castrillo's Paul Valéry y el mundo hispánico (Madrid, 1995), G. Steiner's No Passion Spent: Essays, 1978-1995 (New Haven, 1996), and P. H. Piñero Ramírez's edited collection Descensus ad infernos. La aventura de ultratumba de los héroes (de Homero a Goethe) (Sevilla, 1996).

Finally, we must note that all the articles and notes in this issue are published in either Spanish, French or English. We must understand that future issues will contain essays in other languages as well.

Francisca Vázquez

Ramón Ribé (with the collaboration of María Luz Celaya, Margarita Ravera, Fernanda Rodríguez, Elsa Tragant y Núria Vidal). Tramas creativas y aprendizaje de lenguas (Prototipos de tareas de tercera generación), Barcelona, Universitat de Barcelona, Publicacions, 1997, 306 pp.

The book reviewed here represents, above all, a very interesting and relevant contribution in the complex but equally attractive world of foreign language teaching. The author and his colleagues have succeeded in presenting an exhaustive working corpus which, as I will 
later on explain in more detail, gives a breakdown of the different problems of each educational level in which foreign language teaching is present. Moreover, all the information offered in this book is always supported by exercises and tests of different kinds, which are in turn subjected to a results evaluation process. Both teachers -who can find there reference points to improve the degree of satisfaction in their professional activity- and learners -who are in fact the final addressees of all these initiatives- take part in that evaluation process, as can be seen in chapter 12 , which shows some prototypes that will be useful to judge the research work undertaken by Ribé and his collaborators).

Ramón Ribé is very concerned about the accuracy of terms, which explains why, before presenting any specific materials, he gives precise and up-to-date definitions of the terms, particularly for the two key terms in this work, namely tarea (task) and trama (framework). We must emphasize the importance of the latter term, as it becomes very useful when it comes to establishing the complexity and to designing the objectives of the different exercises carried out in the foreign languages class.

In a very structured way and with a clear presentation, Ribé takes us -between the Introduction and chapter 4- from the traditionally used and nowadays a bit worn-out term -tarea- to a much more modern conception in which tasks are becoming differentiated according to the various fields they cover. Thus, the term tarea is reserved for the socalled tareas de primera generación (first-generation tasks), that is to say, the kind of exercises that can be considered as basic, whereas what has been usually known as tareas de segunda y tercera generación (second- and third-generation tasks), will be given a new denomination: tramas de desarrollo cognitivo (cognitive development frameworks) and tramas de desarrollo creativo (creative development frameworks), respectively.

Taking as his main reference the above mentioned key concepts, Ribe offers -in the first part of the book (chapters 1 to 6) called Aspectos Teóricos (Theoretical Aspects)- a very clear and illustrative characterization of the various factors and variables coming into play from the point of view of teaching (chapter 2), distinguishing as well the problems and features which are peculiar to each educational level. Thus, emphasis is laid in these chapters on such crucial aspects as creativity (chapter 5) -which, as is explained in the book, is present in all age-groups, although differently-, language-processing (chapter 6) or the conditions and factors which shape what Ribé calls la realidad del aula (the :classroom's reality).

Inside this first part are specially worthy of mention the samples of third-generation tasks provided in chapter 3 and based on very different sources, such as general information tourist guides about Barcelona, tales like Little Red Riding Hood, literary works like Counterpoint or El Mundo de Sofia (Sophie's world) or a song by the late Freddie Mercury ('Living on my own'). The variety and appeal of those topics deserves a positive appraisal on my part because it helps motivate students, which optimizes the results obtained with those learning exercises. As is said in the book, the learning process must be closely linked to the life experience of the people taking part in the process. We should never detach that learning process from what surrounds students in their everyday life.

The second part of the book (chapters 7 to 12) offers specific examples of tramas designed as prototypes focusing on the different educational levels (primary education - 
chapter 9-, secondary education -chapter 8-and university education -chapter 10-), as well as the other side of the coin, the training of teachers (chapter 11), who are as essential in the learning process as the students who receive their teaching. This second part is complemented with an introduction on the research carried out so far as regards framework prototypes (chapter 11) and evaluation prototypes (chapter 12), which I referred to at the beginning of this review, essential for both teachers and learners to be able to assess their performance and the practical results of the different activities, projects and tasks done either inside or outside the classroom within the global context we identify as the learning process.

It becomes obvious throughout the book that the different prototypes and tramas proposed are the result of a thorough study and an in-depth research work on the very varied aspects of both the teaching and learning of foreign languages. The information we have access to here is, as is written at the beginning of the book, the final result of the initiative undertaken by a team of enthusiastic researchers, who are also aware of the fact that their effort, however praiseworthy it may be, represents nothing but the foundation stone -maybe the first stone in the building but also indispensable to continue. In this respect, I would like to thank the author for the wide range of bibliography references provided at the end of each chapter.

Finally, the third part of the book -called Estudio de aspectos concretos (Study of specific aspects)-, in chapters 12 to 16, deals with some specific fields separately, namely, the written code (which is the main topic in chapter 13, elaborated by María Luz Celaya and Elsa Tragant), the oral code (which Elsa Tragant and María Luz Celaya tackle in 'chapter 14) and, in chapter 15, what Núria Vidal calls 'el cambio actitudinal' (the change in attitude) which takes place in the class, both on the part of the students and on the teachers' side. All this is complemented with Ramón Ribé's conclusions (chapter 16) in which he describes the philosophy and the objectives of the research work this book has resulted from, when he defends what he calls 'enfoque vivencial' (life-experience approach) as an alternative to most of the current syllabuses or curricula saying that 'aprendizaje como desarrollo, autonomía del alumno y del enseñante, tareas centradas en el alumno,...evaluación del proceso o el rol del profesor como investigador son algunos elementos que no aparecen en absoluto en algunos medios de instrucción...Por lo que respecta al alumno... [cuando se pueden implementar] formas de aprendizaje basadas en un entorno de trabajo autónomo y cooperativo...los resultados sorprenden a los propios aprendientes' (learning as development, independence for both the student and the teacher, student-centred tasks...assessment of the process or the role of the teacher as a researcher are some of the elements which are completely ignored in some instruction schemes...As far as the student is concerned... [when they can be implemented] ways of learning based on research or creative frameworks based on an environment of autonomous and co-operative work...results surprise the learners themselves). 